\title{
Identification, gene expression and genetic polymorphism of zinc finger A20/AN1 stress-associated genes, HvSAP, in salt stressed barley from Kazakhstan
}

Akmaral Baidyussen ${ }^{1 \dagger}$, Maryam Aldammas $^{2 \dagger}$, Akhylbek Kurishbayev $^{1}$, Malika Myrzabaeva ${ }^{1}$, Askar Zhubatkanov ${ }^{1}$, Grigory Sereda ${ }^{3}$, Raisa Porkhun ${ }^{3}$, Sergey Sereda ${ }^{3}$, Satyvaldy Jatayev ${ }^{1 *}$, Peter Langridge ${ }^{4}$, Carly Schramm ${ }^{2}$,

Colin L. D. Jenkins ${ }^{2}$, Kathleen L. Soole ${ }^{2}$ and Yuri Shavrukov ${ }^{2 *}$

From Fifth International Scientific Conference "Plant Genetics, Genomics, Bioinformatics, and Biotechnology" (PlantGen2019)

Novosibirsk, Russia. 24-29 June 2019

\begin{abstract}
Background: A family of genes designated as the Zinc finger A20/AN1 Transcription factors encoding stressassociated proteins (SAP) are well described in Arabidopsis and rice, and include 14 AtSAP and 18 OsSAP genes that are associated with variable tolerances to multiple abiotic stresses. The SAP gene family displays a great diversity in its structure and across different plant species. The aim of this study was to identify all HvSAP genes in barley (Hordeum vulgare L.), to analyse the expression of selected genes in response to salinity in barley leaves and develop SNP marker for HVSAP12 to evaluate the association between genotypes of barley plants and their grain yield in field trials.

Results: In our study, 17 HVSAP genes were identified in barley, which were strongly homologous to rice genes. Five genes, HVSAP5, HVSAP6, HVSAP11, HVSAP12 and HVSAP15, were found to be highly expressed in leaves of barley plants in response to salt stress in hydroponics compared to controls, using both semi-quantitative RT-PCR and qPCR analyses. The Amplifluor-like SNP marker KATU-B30 was developed and used for HvSAP12 genotyping. A strong association $\left(R^{2}=0.85\right)$ was found between KATU-B30 and grain yield production per plant of $50 \mathrm{~F}_{3}$ breeding lines originating from the cross Granal $\times$ Baisheshek in field trials with drought and low to moderate salinity in Northern and Central Kazakhstan.

(Continued on next page)
\end{abstract}

\footnotetext{
* Correspondence: satidjo@gmail.com; yuri.shavrukov@flinders.edu.au

${ }^{\dagger}$ Akmaral Baidyussen and Maryam Aldammas contributed equally to this work.

${ }^{1}$ Faculty of Agronomy, S. Seifullin Kazakh AgroTechnical University,

Nur-Sultan, Kazakhstan

${ }^{2}$ College of Science and Engineering, Biological Sciences, Flinders University, Adelaide, SA, Australia

Full list of author information is available at the end of the article
}

(C) The Author(s). 2020 Open Access This article is licensed under a Creative Commons Attribution 4.0 International License, which permits use, sharing, adaptation, distribution and reproduction in any medium or format, as long as you give appropriate credit to the original author(s) and the source, provide a link to the Creative Commons licence, and indicate if changes were made. The images or other third party material in this article are included in the article's Creative Commons licence, unless indicated otherwise in a credit line to the material. If material is not included in the article's Creative Commons licence and your intended use is not permitted by statutory regulation or exceeds the permitted use, you will need to obtain permission directly from the copyright holder. To view a copy of this licence, visit http://creativecommons.org/licenses/by/4.0/ The Creative Commons Public Domain Dedication waiver (http://creativecommons.org/publicdomain/zero/1.0/) applies to the data made available in this article, unless otherwise stated in a credit line to the data. 
(Continued from previous page)

Conclusions: A group of HVSAP genes, and HVSAP12 in particular, play an important role in the tolerance of barley plants to salinity and drought, and is associated with higher grain yield in field trials. Marker-assisted selection with SNP marker KATU-B30 can be applied in barley breeding to improve grain yield production under conditions of abiotic stress.

Keywords: Barley, Gene expression, Genetic polymorphism, HvSAP, Marker-assisted selection, SNP marker, Stressassociated proteins, Salinity, Zinc finger A20/AN1 transcription factor

\section{Background}

A large group of stress-associated proteins (SAP) is encoded by zinc-finger proteins containing two conservative domains A20/AN1. In humans, these genes act as Tumor necrosis factor, TNF [1] but in plants, SAP genes play an important role in different types of abiotic and biotic stresses, and they are well known as a part of the plant immunity response (Reviewed in [2]). Widely present in plant species, $S A P$ genes remain very conservative structurally but have very diverse functions [3]. Identified firstly in rice [4], 18 OsSAP genes were shown to have a strong similarity to 14 AtSAP genes of Arabidopsis thaliana [5]. SAP genes have also been studied in other plant species like maize [3], tomato [6], grasses Festuca arundinacea and Leymus chinensis [7, 8], wheat [9], as well as cotton [10], plum and apple [11, 12], Brassica napus and Medicago truncatula [13, 14]. However, barley (Hordeum vulgare), an important cereal crop, represents a gap in our knowledge in this area, with no SAP genes as yet described and studied.

Similar to humans, SAP genes in plants are involved in the pathogen-recognition process via membrane-bound receptor-like kinases [15], and in defence mechanisms against bacteria and fungi infections, as shown in the recent examples of tomato SlSAP3 and SISAP4 silencing and over-expression [16, 17]. However, much stronger responses of $S A P$ genes were found in plants in response to various abiotic stresses including drought, salinity, cold and others (Reviewed in [2]).

Regardless of plant species, different SAP genes have specific expression profiles in response to abiotic stresses. All 18 OsSAP genes in rice and 13 identified SISAP genes in tomato were responsive to one or multiple stresses amongst the wide range of abiotic stresses applied [5, 6]. AtSAP10 was reported as strongly involved in the tolerance of Arabidopsis plants to heavy metals and high temperature [18]. For salinity, most SAP genes in rice, Arabidopsis and tomato were responsive to $\mathrm{NaCl}$ at the seedling stage $[5,6]$, while 33 out of 37 GhSAP genes were expressed in one-month-old cotton plants after exposure for $2 \mathrm{~h}$ of strong salinity stress (300 mM NaCl) [10]. The same strong level of salinity applied to young plants of Medicago truncatula for 2$12 \mathrm{~h}$ resulted in up-regulation of four $M t S A P$ genes and down-regulation of five other genes [14]. One-month- old plants of the perennial grass, Leymus chinensis, were exposed to an even higher concentration of $\mathrm{NaCl}(400$ $\mathrm{mM}$ ) for 6-24 h, and transcript levels of LcSAP continued to increase [8].

Drought is reported to trigger strong expression of MdSAP15, MdSAP25 and MdSAP29 genes in apple [12] but, in contrast, OsSAP7 gene was down-regulated in rice shoots [19]. The expressions of FaSAP (closest homolog of OsSAP8) in the grass species, Festuca arundinacea, and PpSAP1 in plum (Prunus persica) were also highly up-regulated in plants under either salinity or drought [7, 11]. Showing a comparable trend, two SAP genes (BnaA03g47350D and BnaC07g39590D), homologous to AtSAP10 and OsSAP3 / OsSAP5, were induced with salt and dehydration with PEG in roots of Brassica napus as determined by the RNA-Seq technique [13].

Over-expression of AtSAP10, OsSAP7 and MdSAP15 (closest homologs of OsSAP4 / OsSAP8) transgenes in Arabidopsis were very beneficial in improving plant tolerance to heavy metals and drought, respectively [12, 18, 19]. Transgenic tobacco plants over-expressing LmSAP from ornamental alyssum, Lobularia maritima, showed high expression of the transgene, with A20 and AN1 domains specifically involved in salinity/osmotic and oxidative stress responses, respectively [20]. In transgenic wheat and rice with over-expressed $S A P$, either higher grain yield or no net effect under various abiotic stresses was reported (Reviewed in [2]).

Variability in $S A P$ gene expression in response to abiotic stresses is well documented in various plant species (Reviewed in [2]) but very little information has been recorded where such expression is associated with haplotypes, mutations or genetic polymorphism. In this context, molecular markers can be designed to indicate strong or weak associations between a haplotype and expression of a particular SAP gene. For example, a strong association was reported between three molecular markers surrounding the TaSAP1-A1 gene and agronomically important traits like 1000 grain weight, number of grains per spike, spike length, peduncle length and total number of spikelets per spike in 300 bread wheat accessions grown in both drought and well-watered conditions [9]. Among a wide range of molecular markers, SNP (Single nucleotide polymorphisms) are very popular, and the recently developed Amplifluor-like SNP markers [21] were selected and 
applied in the current study, chosen from a very diverse range of SNP detection methods (Reviewed in [22]).

In addition to natural variation, hybrid populations and their progenies can also be used for genetic analysis of a preferred haplotype of the $S A P$ gene to indicate segregation pattern and the type of gene inheritance. Association analysis of the $S A P$ genetic background and plant performance in a stressed environment can provide direct information supporting the role and function of the SAP gene.

Barley (Hordeum vulgare L.) is a diploid plant species from the grass family and Triticeae tribe. The barley haploid genome size is about $5.3 \mathrm{~Gb}$, with seven chromosomes, making it one of the largest of the recently sequenced genome of diploid species to date [23]. Barley plants show some tolerance to several abiotic stresses and can grow in relatively harsh and unfavourable environments. However, the grain yield of barley could be improved with better understanding of the mechanisms for tolerance to such abiotic stresses as drought and salinity [24]. In the very complicated gene-regulatory network system of barley plants, $H \nu S A P$ genes potentially play an important role in the coordinated response and signalling system combatting abiotic stresses.

In the current study, within the framework of an International collaborative project, as indicated in the Funding section, local barley cultivars from Kazakhstan and one generated hybrid were used. With such a large territory available for field crops in Kazakhstan, strong drought and high salinity are very typical of some areas. Barley seed is in strong demand for animal feed and, therefore, a better understanding of the genetic mechanisms of barley plants' tolerance to abiotic stresses can aid not only local agri-business, but also be beneficial for researchers and breeders working with barley and other crops in many countries.

The aims of this study were: (1) to identify a comprehensive list of HvSAP genes present in the barley genome and to compare them with the reference genome of rice; (2) to study and select the HvSAP genes most responsive to salinity using semi-quantitative and qRTPCR; (3) to search for natural polymorphisms of HvSAP12 among parents of a barley hybrid population; (4) to develop an SNP marker for hybrid plant genotyping and marker-assisted selection; and (5) to evaluate the association between selected hybrid genotypes and their phenotypes for grain yield performance in the strong drought and low to moderate salinity-affected environments of Northern and Central Kazakhstan.

\section{Results}

Identification of HvSAP candidate genes using bioinformatics approaches

During screening of SNPs in the barley database (http:// bioinf.scri.ac.uk/barley_snpdb), the SNP ID: ABC08579 was found as a potentially interesting candidate gene. The annotation of the closely related rice accession AAP37480, putative A20/AN1-type zinc finger protein in Oryza sativa, group japonica was indicated. A search for a barley homologous gene using IPK (https://webblast.ipk-gatersleben.de/barley_ibsc/viroblast.php) and NCBI databases (https://www.ncbi.nlm.nih.gov) revealed that the identified SNP is present in the HvSAP12 gene encoding a Stress-associated protein. Similar to rice, HvSAP12 belongs to a Transcription factor A20/AN1type zinc finger protein group. The annotated barley genes HORVU2Hr1G053670 and AK363382 were identified, respectively, from the IPK and NCBI databases for $H \nu S A P 12$, and $17 H \nu S A P$ genes were found in total in the barley genome, strongly homologous to rice genes (Table 1). Small rearrangements in the barley genome were evident, where two HvSAP genes were duplicated (HvSAP9a and HvSAP17a), but three other genes (HvSAP8, HvSAP13 and HvSAP18) were lost compared to the 18 OsSAP genes in rice [5].

A molecular phylogenetic tree of the $17 \mathrm{H \nu SAP}$ genes (Fig. 1) was identical in order and pattern between the gene nucleotide and the deduced protein amino acid sequences. The analysis revealed the closest molecular similarity between $H \nu S A P 12$ and the HvSAP6, with relatively close similarity to HvSAP5 and HvSAP4/HvSAP8. $H \nu S A P 3$ was isolated, but still closer than the most isolated group of $H v S A P 16$ and paired $H v S A P 17$ and HvSAP17a genes (Fig. 1).

To better define the similarity between the encoded protein HvSAP12 (accession BAJ94586) with SAP protein sequences from other monocot plant species, a phylogenetic dendrogram was produced based on available monocot protein sequences in the NCBI database (https://www.ncbi.nlm.nih.gov) (Fig. 2).

\section{Analysis of HvSAP gene expression using semi- quantitative RT-PCR}

Semi-quantitative RT-PCR analysis of 17 identified $H v S A P$ genes with bulked cDNA samples from stressed plants revealed five highly expressed genes: HvSAP5, HvSAP6, HvSAP11, HvSAP12 and HvSAP15 (Fig. 3). Two genes, HvSAP1 and HvSAP16, showed less intense but still clear expression levels, while the remaining $H \nu S A P$ genes showed no or very poor expression, including multiple bands for the HvSAP9a gene. The five highly expressed genes were selected for further study.

\section{Expression analysis of five selected HvSAP genes}

Four out of five $H \nu S A P$ genes examined had relatively high or very high expression after 3 days and especially after 7 days exposure to salt stress (Fig. 4). The greatest increase in transcript levels were found for HvSAP5 (7fold), HvSAP6 (12-fold), HvSAP12 (6-fold), and HvSAP15 
Table 1 List, annotation and distribution of HVSAP genes in the barley genome and their corresponding homologs in rice. The HVSAP12 and homologs are indicated in Bold

\begin{tabular}{|c|c|c|c|c|c|c|}
\hline Gene & $\begin{array}{l}\text { Gene/protein ID in IPK } \\
\text { database }\end{array}$ & Chromosome & $\begin{array}{l}\text { Gene ID in NCBI } \\
\text { database }\end{array}$ & $\begin{array}{l}\text { Protein ID in NCBI } \\
\text { database }\end{array}$ & $\begin{array}{l}\text { Protein Uni } \\
\text { Ref100 }\end{array}$ & $\begin{array}{l}\text { Gene ID in rice } \\
\text { database }\end{array}$ \\
\hline HVSAP1 & HORVU5Hr1-G072920 & $5 \mathrm{H}$ & $\begin{array}{l}\text { AK372328, } \\
\text { AK357531 }\end{array}$ & $\begin{array}{l}\text { BAK03526, } \\
\text { BAJ88745 }\end{array}$ & A2Z2J5 & LOC_Os09g31200 \\
\hline HVSAP2 & $\begin{array}{l}\text { HORVU3Hr1-G067990 } \\
\text { MLOC_39637 }\end{array}$ & $3 \mathrm{H}$ & No match & No match & Q942F8 & LOC_Os01g52030 \\
\hline HVSAP3 & HORVU2Hr1-G042070 & $2 \mathrm{H}$ & No match & No match & Q5JN07 & LOC_Os01g56040 \\
\hline $\begin{array}{l}\text { HVSAP4 } \\
\text { (HVSAP8) }\end{array}$ & HORVU6Hr1-G033550 & $6 \mathrm{H}$ & $\begin{array}{l}\text { AK354794, } \\
\text { AK250311 }\end{array}$ & BAJ86013 & $\begin{array}{l}\text { Q6H7P8, } \\
\text { A2YEZ6 }\end{array}$ & $\begin{array}{l}\text { LOC_Os02g10200, } \\
\text { LOC_Os06g41010 }\end{array}$ \\
\hline HVSAP5 & MLOC_43986 & $7 \mathrm{H}$ & AK372340 & BAK03538 & Q6H754 & LOC_Os02g32840 \\
\hline HVSAPG & HORVU5Hr1-G104240 & $5 \mathrm{H}$ & AK370302 & BAK01503 & Q852K5 & LOC_Os03g57890 \\
\hline HVSAP7 & HORVU5Hr1-G103940 & $5 \mathrm{H}$ & No match & No match & Q852K6 & LOC_Os03g57900 \\
\hline HVSAPG & $\begin{array}{l}\text { HORVU2Hr1-G022940 } \\
\text { MLOC_73029 }\end{array}$ & $2 \mathrm{H}$ & No match & No match & Q7Y1W9 & LOC_Os07g07350 \\
\hline HVSAP9a & $\begin{array}{l}\text { HORVU2Hr1-G036250 } \\
\text { MLOC_17636 }\end{array}$ & $2 \mathrm{H}$ & No match & No match & Q7Y1W9 & LOC_Os07g07350 \\
\hline $\begin{array}{l}\text { HVSAP10 } \\
\text { (HVSAP9) }\end{array}$ & HORVU5Hr1-G103980 & $5 \mathrm{H}$ & No match & No match & $\begin{array}{l}\text { Q69LE0, } \\
\text { Q7Y1W9 }\end{array}$ & $\begin{array}{l}\text { LOC_Os07g07400, } \\
\text { LOC_Os07g07350 }\end{array}$ \\
\hline HVSAP11 & HORVU7Hr1-G050270 & $7 \mathrm{H}$ & AK359310 & BAJ90521 & Q84PD8 & LOC_Os08g39450 \\
\hline $\begin{array}{l}\text { HvSAP12 } \\
\text { (HVSAP9) }\end{array}$ & $\begin{array}{l}\text { HORVU2Hr1-G053670 } \\
\text { MLOC_79442 }\end{array}$ & $2 \mathrm{H}$ & AK363382 & BAJ94586 & $\begin{array}{l}\text { Q6Z541, } \\
\text { Q7Y1W9 }\end{array}$ & $\begin{array}{l}\text { LOC_Os08g33880, } \\
\text { LOC_Os07g07350 }\end{array}$ \\
\hline HVSAP14 & HORVU5Hr1-G104360 & $5 \mathrm{H}$ & No match & No match & Q852K8 & LOC_Os03g57920 \\
\hline HVSAP15 & HORVU1Hr1-G032850 & $1 \mathrm{H}$ & No match & No match & Q0DJC7 & LOC_Os05g23470 \\
\hline HVSAP16 & HORVU2Hr1-G038760 & $2 \mathrm{H}$ & $\begin{array}{l}\text { AK367174, } \\
\text { AK360983 }\end{array}$ & BAJ98377 & Q0D5B9 & LOC_Os07g38240 \\
\hline HvSAP17 & HORVU5Hr1-G059890 & $5 \mathrm{H}$ & AK370364 & BAK01565 & Q6H595 & LOC_Os09g21710 \\
\hline HvSAP17a & HORVU5Hr1-G059900 & $5 \mathrm{H}$ & AK370364 & BAK01565 & Q6H595 & LOC_Os09g21710 \\
\hline
\end{tabular}

(11-fold). Two genes, HvSAP6 and HvSAP12 (Fig. 4b and d), showed similar expression levels on Days 3 and 7 in three out of four of the studied cultivars, while transcripts of HvSAP5 and HvSAP15 (Fig. 4a and e) were significantly higher on Day 7 in all four studied barley genotypes. In Control (non-stressed) plants, the expression level of the four genes varied from very low (0.35 Relative expression units in $H \nu S A P 15)$ to extremely low

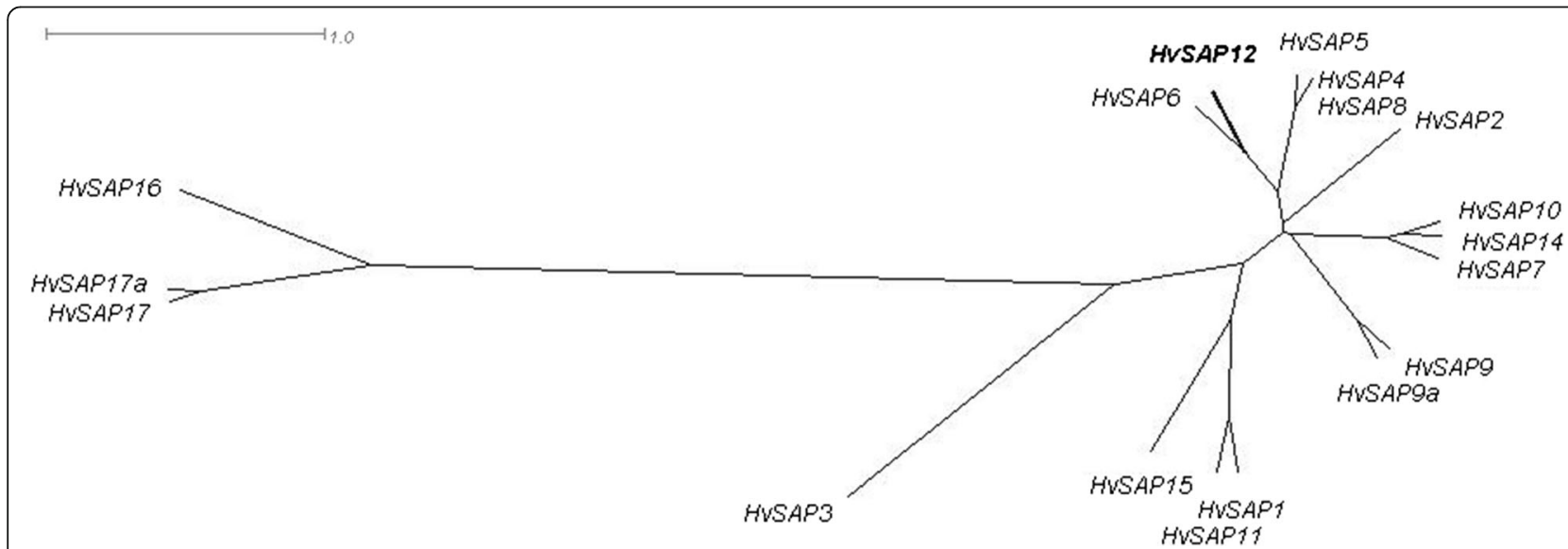

Fig. 1 Molecular phylogenetic tree of 17 identified HVSAP genes based on their sequences in the barley genome. Unrooted Consensus tree with Equal angle dendrogram was generated by the program SplitsTree4 (http://www.splitstree.org). The position of the HvSAP12 gene with the described SNP is indicated in Bold 


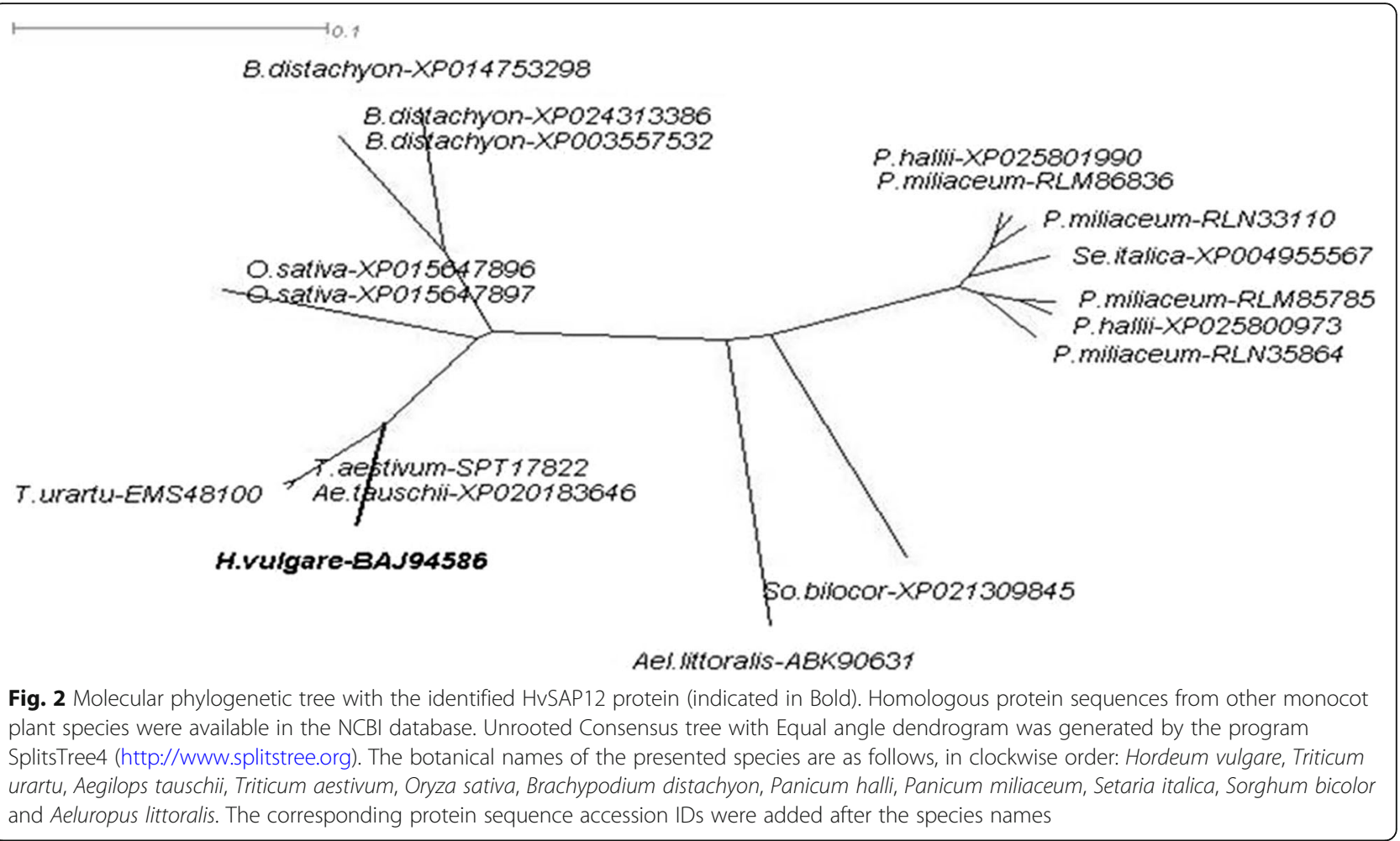

in HvSAP5, HvSAP6 and HvSAP12 (Fig. 4f). Only a single gene, $H v S A P 11$ (Fig. 4c), had an expression profile very different from the other four studied $H \nu S A P$ genes. Firstly, the initial level of $H v S A P 11$ expression varied between 0.5 and 1.7 Relative expression units in all four studied cultivars (Fig. 4c), which was significantly higher than recorded in the other four HvSAP genes (Fig. 4f). Under salt stress, expression of HvSAP11 was significantly (2.5-fold) increased at Day 7 in Granal, but was down-regulated during all periods of the experiment (314 days) in Tzelinniy golozerniy (Fig. 4c). It is too premature to draw any conclusions about correlations between the productivity of the four studied barley cultivars in salt- and drought-affected environments and the presented expression profiles of the five studied $H \nu S A P$ genes.

\section{Genotyping of the segregating population Granal $x$ Baisheshek for the HvSAP12 gene using an Amplifluor SNP marker}

A single clear SNP was identified in the 3'-UTR region of the HvSAP12 gene in Granal and Baisheshek, parents of the $\mathrm{F}_{3}$ segregating population (Additional file 1, Fig. S1). Based on this SNP, the Amplifluor-like SNP marker

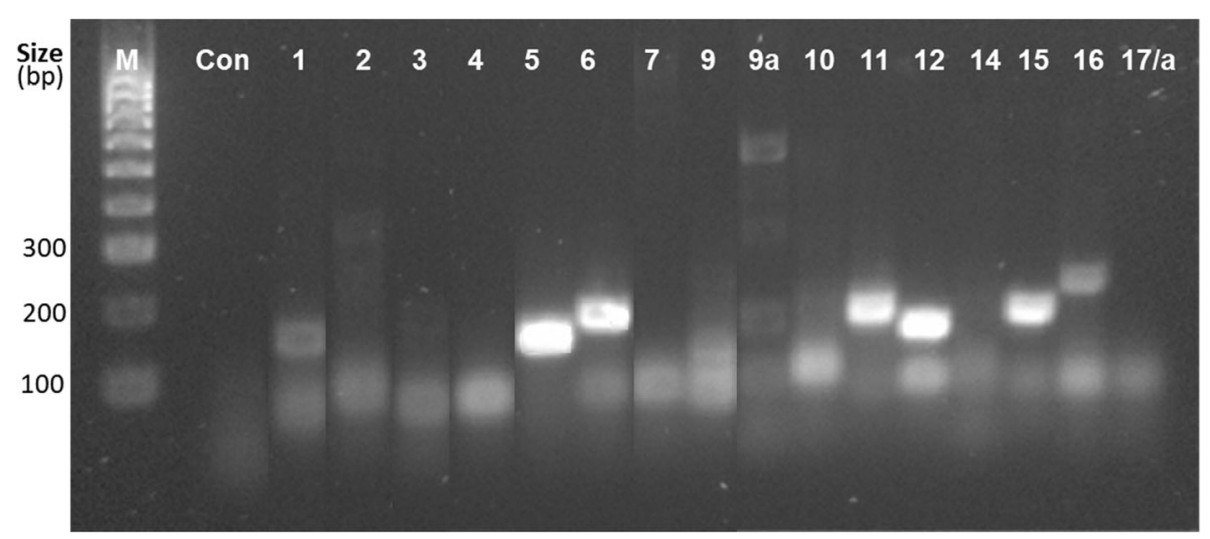

Fig. 3 Expression of 17 HvSAP genes (shown at the top) detected by semi-quantitative RT-PCR. CDNA was synthesised from leaves of plants of the four cultivars grown under salt stress and compared to parental Controls (Con). M, 100 bp DNA ladder (Bioline) 


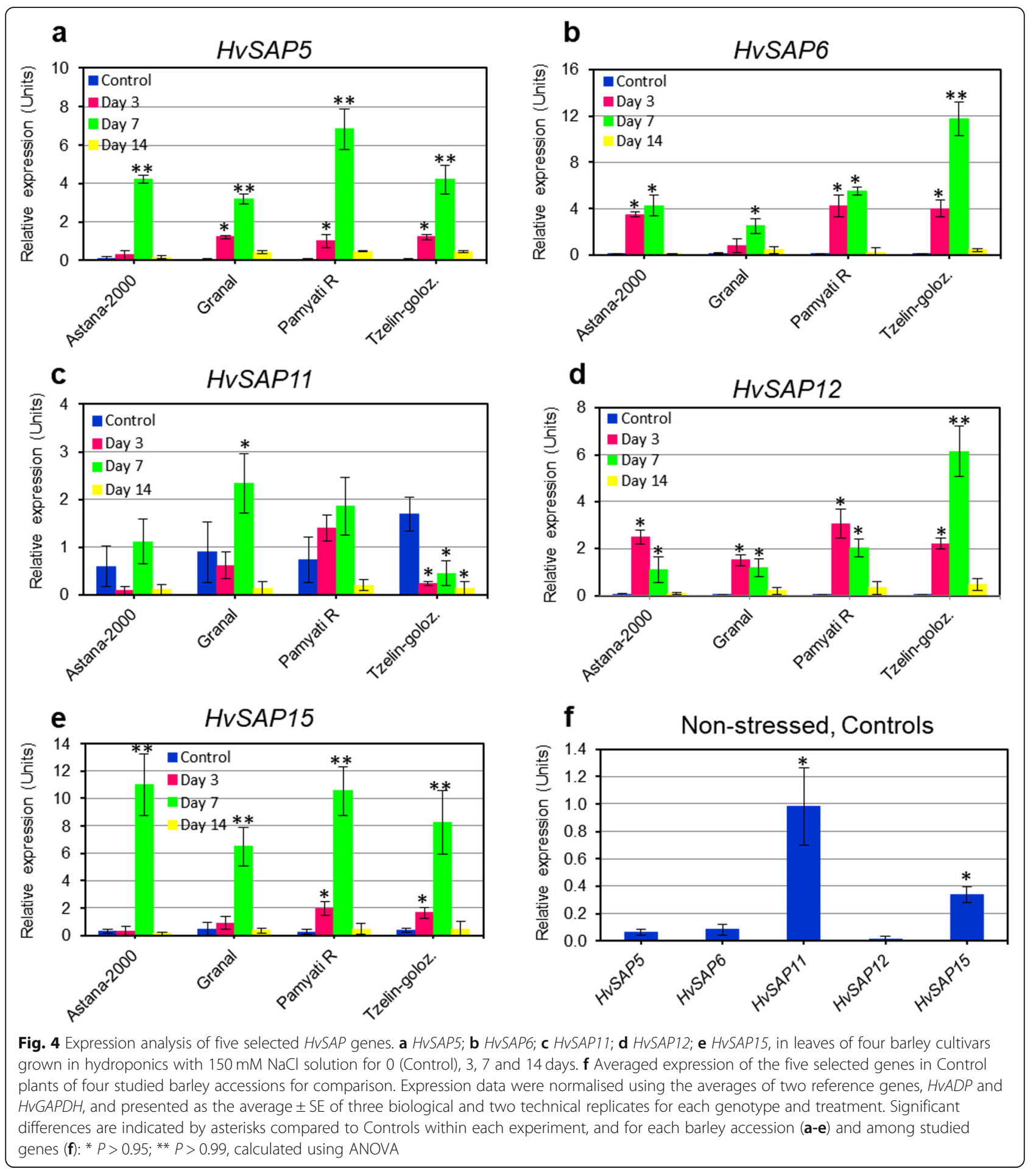

KATU-B30 was developed and used to score 50 breeding lines produced from the $\mathrm{F}_{3}$ progeny of this cross. The genotyping results using the KATU-B30 SNP marker showed good discrimination of alleles identical to those in the parents (Fig. 5). The genotyping results of $H \nu S A P 12$ were used for further comparison with plant phenotypes.
Phenotyping and grain yield performance of $F_{3}$ breeding lines from the segregating population Granal $x$ Baisheshek

In field trials affected by drought and a low-moderate salinity level over two years, phenotyping analysis of grain yield performance of 50 breeding lines produced from $F_{3}$ progeny showed a continuous distribution 


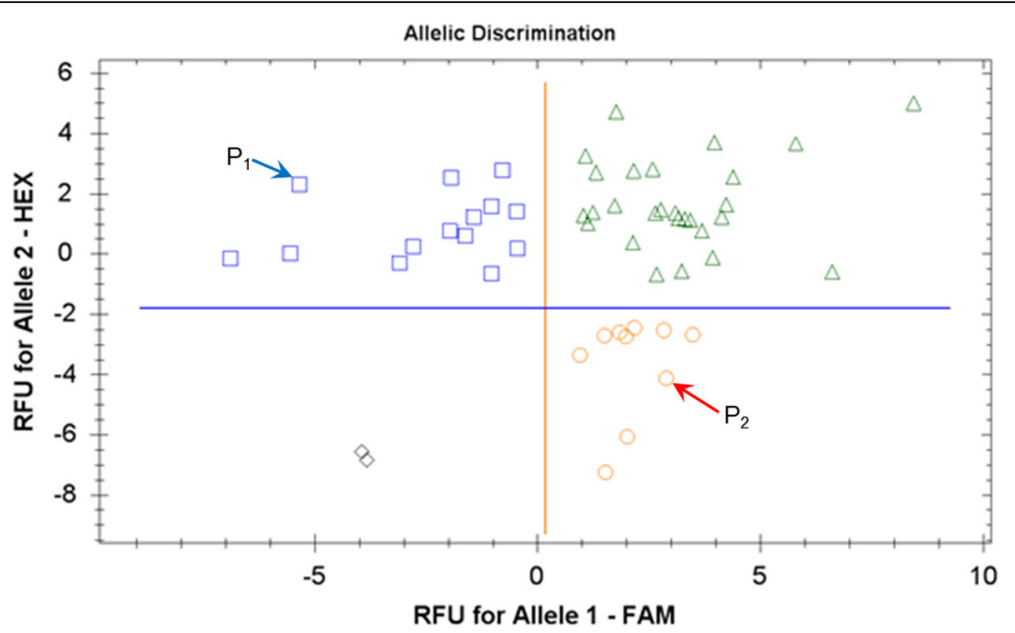

Fig. 5 Allele discrimination for the Amplifluor-like SNP marker KATU-B30. Fifty $F_{3}$ breeding lines from the segregating population Granal $X$ Baisheshek were used. Parental genotypes are designated as: $P_{1} \mathrm{P}_{1}$, Granal, and $\hat{\delta} \mathrm{P}_{2}$, Baisheshek. Relative Fluorescence Units (RFU) for fluorophores FAM and HEX were transformed automatically into genotyping of alleles 1 and 2, respectively, using a BioRad CFX96 Real-Time PCR Detection System Instrument

(Fig. 6). However, groups of genotypes scoring differently for the KATU-B30 SNP marker were clearly distinguished between the lowest and highest grain yields $\quad<2.6$ and $>2.6 \mathrm{~g}$ per plant, respectively), and did not overlap (Fig. 6). The two groups of breeding lines with lowest and highest grain yields included homozygotes (indicated in dark blue and in red, respectively, in Fig. 6), and a mixture with heterozygotes (shown in light blue and pink).

Alleles of $H v S A P 12$, derived from maternal parent Granal and designated as blue squares in Fig. 5, were associated with lower yielding breeding lines as indicated by dark and light blue bars in Fig. 6. Respectively, HvSAP12 alleles originating from the paternal parent Baisheshek are indicated with red circles (Fig. 5) and by red and pink bars in genotypes with higher grain yields per plant (Fig. 6). A very strong association $\left(R^{2}=0.85\right)$ was found between HvSAP12 genotyping (Fig. 5) and grain yield phenotyping (Fig. 6).

\section{Discussion}

A large family of $H v S A P$ genes was identified for the first time and their expressions were characterised in barley plants, in both hydroponic experiments with control (non-stressed) and $\mathrm{NaCl}$ treatment, as well as in field trials in a dry environment with low-moderate salinity.

There is very little published information concerning $S A P$ gene expression in different plant species grown under favourable conditions. In tomato, SISAP genes

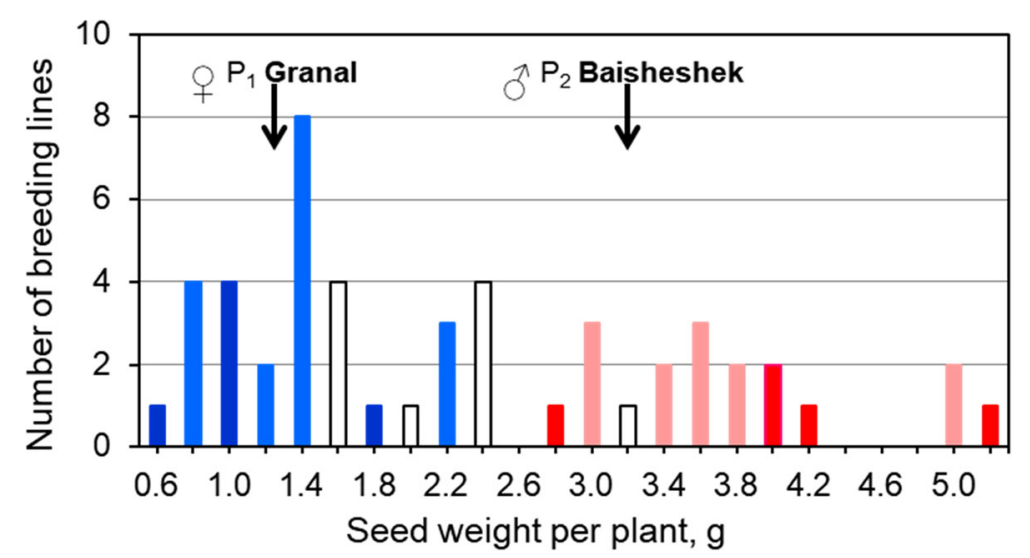

Fig. 6 Histogram of seed yield from $50 \mathrm{~F}_{3}$ breeding lines produced from the segregating population Granal $\times$ Baisheshek. The breeding lines were tested in field trials in Northern and Central Kazakhstan during the dry seasons of 2017-2018 with a low-moderate level of soil salinity. Yield of the parents, $\rho_{1} \mathrm{P}_{1}$, Granal, and $\hat{\sigma} \mathrm{P}_{2}$, Baisheshek, is indicated at the top by arrows. Dark blue and dark red bars indicate completely homozygous breeding lines for the KATU-B30 SNP marker, while light blue and pink bars represent mixed breeding lines containing homo- and heterozygotes alleles 1 and 2 of the SNP marker, respectively. Clear bars relate to heterozygotes of KATU-B30 SNP 
show much stronger similarity to Arabidopsis than monocot plant species; nonetheless, a comparison of tomato with barley $H \nu S A P$ transcripts is noteworthy. Very high expressions of SlSAP1 and SlSAP10 were found in 9-day-old tomato seedling without any stress [6]. These genes are closely related to OsSAP1, OsSAP11 and OsSAP15 in rice, which perfectly matches our results for HvSAP11 and HvSAP15, which showed the highest transcript levels in non-stressed barley plants (Fig. 4f). Two other barley genes identified in our study, HvSAP5 and $H \nu S A P 6$, showed smaller but still recognisable levels of gene expression in plants grown in favourable conditions. Therefore, our results are similar to those in tomato, where SISAP4, SISAP5 and SISAP9 were clustered in the same clade of the phylogenetic tree [6].

In our study, five out of 17 identified HvSAP genes showed high expression profiles under salt stress, while other $H \nu S A P$ genes had no or very low transcript levels. For comparison, in rice, all five orthologue genes were up-regulated in response to salinity stress [5]. The highest level of 3.5-fold increased expression was reported for OsSAP5 and OsSAP12, followed by OsSAP6 and OsSAP11 (3-fold), and OsSAP15 (1.5-fold). In general, our results for the five $H v S A P$ genes show a similarity to those published for rice, except that HvSAP15 compared to OsSAP15 transcripts showed very high (6-11-fold) and relatively small (1.5-fold) expression in barley and rice, respectively.

Nevertheless, more conflicting observations were made in the comparison between other OSSAP and HVSAP genes. Three genes, OsSAP7, OsSAP10 and OsSAP14, showed 5.5-, 9- and 10-fold up-regulation in rice seedling under salt stress [5], while orthologous barley genes (HvSAP7, HvSAP10 and HvSAP14) in our study did not show any amplification with bulked cDNA in semiquantitative RT-PCR, and as a result were excluded from further study. There are several possible reasons for such notable differences in orthologous gene expression. Firstly, four barley cultivars were used in our study, which is significantly more representative compared to the single rice accession published by Vij and Tyagi [5]. In that experiment, rice seedlings were grown to 7 days in trays lined with wet cotton prior to $\mathrm{NaCl}$ application, while barley plants in our experiment were three weeks old and grown in hydroponics with Growth solution. The rice seedlings were exposed to $200 \mathrm{mM} \mathrm{NaCl}$ for a very short time $(6 \mathrm{~h})$, while leaves from barley plants in our experiments were sampled after 3, 7 and 14 days, as a long-term salinity treatment with $150 \mathrm{mM} \mathrm{NaCl}$.

However, from our point of view, the major important difference between the experiments with rice [5] and our experiments with barley is methodological, which can dramatically change the interpretation of the results. Although it was not explicitly written, we can presume that rice seedlings were simply transferred from the wet tray into a container with $200 \mathrm{mM} \mathrm{NaCl}$ and exposed for $6 \mathrm{~h}$ [5]. Such a sudden transfer (in one step) of plants from non-stressed conditions into solution with $200 \mathrm{mM} \mathrm{NaCl}$ would likely cause 'osmotic shock' and cell plasmolysis, with protoplasts detaching from the cell wall, particularly in roots. Therefore, the gene expressions reported (including SAP genes) were possibly the result of 'salt shock' rather than 'salt stress' as occurs with gradual (in several steps) $\mathrm{NaCl}$ application, as described earlier [25]. In our experiments with barley plants, high transcript levels of five genes (HvSAP5, HvSAP6, HvSAP11, HvSAP12 and HvSAP15) were found after gradual elevation of $\mathrm{NaCl}$ concentration in Growth solution, and these genes indeed were responsive to salt stress. In contrast, the three reported genes in rice, OsSAP7, OsSAP10 and OsSAP14 [5], were possibly responding to the strong osmotic/salt shock rather than salt stress and therefore these results should be interpreted with regards to the method of $\mathrm{NaCl}$ application.

A similar situation arises for the comparison of $H v S A P$ gene expression in barley with SISAP genes in 9-day-old tomato seedlings transferred into media with $200 \mathrm{mM}$ $\mathrm{NaCl}$ for 1 and $8 \mathrm{~h}$ [6]. All five HvSAP genes identified as responsive to gradual salt stress have similarity with the corresponding genes in tomato, while the group including SISAP6, SISAP12 and SISAP13 genes were likely expressed in response to salt shock.

In general, absolute expression levels are not always a reliable indicator of the importance of gene function. However, the studied HVSAP genes showed higher or lower expression profiles (more or less transcript) in response to salt stress. Further investigation can prove which of these candidate genes are functionally more important for plant responses to stress. Nevertheless, it seems unlikely that studied genes recording only low expression and a small amount of transcript in response to salinity could have a more important functional role in plant tolerance.

Salinity and dehydration tolerance have a common response component - osmotic regulation in cells. Therefore, it is not surprising that most SAP genes show similar trends in co-expression in response to either salinity or rapid dehydration in detached (desiccated) rice and tomato leaves [5, 6]. In the natural environment, drought and salinity also often accompany each other. In this regard, one of the more highly expressed genes in barley, HvSAP12, seems to be involved in the synchronised reaction of plants to drought and salinity, particularly in field trials. In the literature, there is only one study, in wheat, which reports a strong association of a haplotype with beneficial alleles of TaSAP1 with agronomically important traits such as grain weight, components of spike productivity and grain yield per plants 
under drought and in well-watered conditions [9]. Therefore, our results on the association, using 50 barley breeding lines from $F_{3}$ progenies of a $G \times B$ cross, between the KATU-B30 SNP marker for HvSAP12 and their grain yield per plant phenotype in dry and saltaffected field trials are similar and now add to the findings presented for bread wheat by Chang et al. [9].

However, the clusters used for allele discrimination for the KATU-B30 SNP marker were quite loosely grouped in our study, which is typical for self-developed Amplifluorlike SNP markers. Nevertheless, the alleles automatically determined by the qPCR instrument software were verified manually and compared to genotypes of the parents to ensure confidence in the results.

Marker-assisted selection based on well-established and experimentally-verified functional molecular markers can be effective for selecting the best genotypes in bread wheat plants grown in drought-prone environments [9] and in barley plants under drought and salinity stress (current study). Therefore, application of molecular markers like the KATU-B30 SNP developed here, can help to speed-up the breeding process in barley for improvement of grain production in the harsh stress-affected environment of Kazakhstan, and potentially many other countries.

\section{Conclusions}

In barley, 17 HvSAP genes encoding Stress-associated proteins were identified in our study. Five genes, HvSAP5, HvSAP6, HvSAP11, HvSAP12 and HvSAP15, were found to be highly expressed in leaves of barley plants in response to salt stress in hydroponics compared to controls, using both semi-quantitative RT-PCR and qPCR analyses. SNP marker KATU-B30 was developed for HvSAP12. This and other HvSAP genes play a definite role in the tolerance of barley plants to salinity and drought, with an association with higher grain yield shown in field trials. Marker-assisted selection with SNP marker KATU-B30 can be applied in barley breeding to improve grain yield production under conditions of abiotic stress.

\section{Material and methods}

Plant material

Four barley cultivars from Kazakhstan developed for animal feed production were used in this study: Astana2000, a standard barley cultivar in Kazakhstan with high grain yield and tolerance to drought and salinity; Granal, a parent of the segregating population with elite grain quality [26] and relatively sensitive to abiotic stresses; Pamyati Raisi, an elite high-yielding tolerant barley feed cultivar in Kazakhstan; and Tzelinniy golozerniy, a hullless or 'naked-seed' local cultivar producing fewer grains under drought and salinity. Based on previous results, an $\mathrm{F}_{2}$ hybrid population was produced from the cross between barley cultivars Granal and Baisheshes (highyielded in dry conditions), with manual emasculation, isolation and controlled pollination conducted, and provided by Grigory Sereda (A.F. Khristenko Karaganda Agricultural Experimental Station, Karaganda Region, Kazakhstan). Seeds of barley cultivars and the propagated $F_{2}$ segregating population were provided for this study by G. Sereda in the framework of the International collaborative research project. A small number of seeds can be provided to researchers upon request.

\section{Salinity stress in hydroponics and collection of leaf samples}

Seeds were germinated on wet filter paper in Petridishes at room temperature for five days and seedlings were transferred into a hydroponics set-up using the described method [27] with the following modifications. Four tubs, each with a $12 \mathrm{~L}$ capacity, were covered with lids drilled with holes $1 \mathrm{~cm}$ in diameter. A foam piece was gently wrapped around the middle of the transferred seedling for support, enabling plants to be secured in the holes with their roots suspended in the Growth solution. Constant aeration of the media was provided by aquarium pumps. Further details, including the composition of the Growth solution and an image of the hydroponics setup with growing plants are presented in (Fig. $5 \mathrm{a}$ and $\mathrm{b}$ in [28]). The $\mathrm{pH}$ of the hydroponic solution remained in the near neutral range $(\mathrm{pH}=6.5-7.0)$ throughout the experiment, as confirmed by regular monitoring with a $\mathrm{pH}$ meter (Activon, Model 20, Adelab Scientific, Australia) with no further adjustment required. The Growth solution was topped up with water daily and replaced completely every 10 days. When plants reached three-weeks old, $\mathrm{NaCl}$ was added to two boxes (designated as 'salt-stressed'), by adding $25 \mathrm{mM} \mathrm{NaCl}$ increments, twice daily, for three days, to reach a final concentration of $150 \mathrm{mM} \mathrm{NaCl}$, to avoid sudden salt shock [25]. Supplementary $\mathrm{CaCl}_{2}$ was added to maintain constant calcium activity as in the initial Growth solution $\left(0.98 \mathrm{mM} \mathrm{Ca}^{2+}\right)$ [29]. Two tubs with Control plants were grown identically without addition of $\mathrm{NaCl}$ and $\mathrm{CaCl}_{2}$.

All leaves were sampled from three individual plants separately into $10 \mathrm{ml}$ plastic tubes, making three independent biological replicates for each genotype, treatment and collection time-points at Day 0, 3, 7 and 14 after salt application. Tubes with leaf samples were immediately frozen in liquid nitrogen and kept at $-80^{\circ} \mathrm{C}$ until RNA extraction.

\section{Field trial tests}

Field trials were conducted in the research fields of S. Seifullin Kazakh AgroTechnical University, Nur-Sultan, in Northern Kazakhstan, and of A.F.Khristenko Karaganda Agricultural Experimental Station, Karaganda 
Region, in Central Kazakhstan, during the 2017 and 2018 seasons, with dry conditions. The salinity level was very low after seed sowing into wet soil $(\mathrm{EC}=1-$ $3 \mathrm{dS} / \mathrm{m}$ ) but gradually increased during the dry growing season until it reached a mild level $(E C=4-6 \mathrm{dS}$ / $\mathrm{m})$. Total rainfall was $107-130 \mathrm{~mm}$ during the vegetative growth period, lower than the average of 150$166 \mathrm{~mm}$ that was observed over many previous years in these regions. Two-row plots were sown, $1 \mathrm{~m}$ in length with $5 \mathrm{~cm}$ between plants in rows and $20 \mathrm{~cm}$ between rows. Four randomised replicates were used in each field trial over the two years of testing. Total grain yield was measured for all plants harvested in each plot and re-calculated as grams per plant.

\section{Identification of the 'Gene of Interest' using bioinformatics and molecular phylogenetic comparative analysis}

The barley SNP database (http://bioinf.scri.ac.uk/barley_ snpdb) was used to search and select a single target gene or 'Gene of Interest' for further research. BLAST analysis of the genetic fragments containing the SNP was applied to identify the full-length target gene using the Nucleotide collection of barley in the NCBI database (https:// blast.ncbi.nlm.nih.gov).

Bioinformatics methods were applied to identify the full-length nucleotide sequence of HvSAP, and its corresponding polypeptide sequence was used for both BLASTN and BLASP in NCBI and in the IPK Barley BLAST Server (https://webblast.ipk-gatersleben.de/barley_ibsc/viroblast.php). A comparison with the rice genome was made using the Rice Gene Annotation web-site (http://rice.plantbiology.msu.edu/annotation.shtml).

Chromosome locations of all $H \nu S A P$ genes in the barley genome were found using PGSB, Plant Genome and Systems Biology, Barley Project web-site (http://pgsb.helmholtz-muenchen.de/plant/barley/fpc/searchjsp/index.jsp) and checked with the IPK Barley BLAST Server.

The molecular dendrograms of both nucleotide sequences in SAP genes and amino acid sequences in SAP polypeptides from barley and other monocot plants were constructed using the SplitsTree4 program (http://www. splitstree.org) [30]. The algorithm of Unrooted Consensus tree and Equal angle dendrogram option was used for preparation of both SAP genes and SAP polypeptide phylogenetic trees.

\section{RNA extraction, CDNA synthesis, semi-quantitative PCR and $\mathrm{qPCR}$ analysis}

Three individual plants of each cultivar were selected from each hydroponic tub (salt stress and Controls) for each collection time-point. Frozen leaf samples were ground in 10-ml tubes with two 9-mm stainless steel ball bearings using a Vortex mixer. TRIzol-like reagent was used for RNA extraction, following the protocol described earlier [27] with a subsequent RNA quality check through electrophoresis of $1 \mu \mathrm{l}$ of each RNA sample on a $1.5 \%$ agarose gel and quantification of RNA on a NanoDrop (ThermoFisher, USA). All cDNAs were synthesised from $2 \mu \mathrm{g}$ of each RNA sample that passed quality control, after $1 \mu \mathrm{l}$ of DNase treatment (NEB Biolab, England) with a $15 \mathrm{~min}$ incubation at room temperature $\left(22^{\circ} \mathrm{C}\right)$, and the use of Protoscript-II Reverse Transcriptase kit (NEB Biolab, England) following the manufacturer's instructions. The quality of all cDNA samples was confirmed by PCR with products generated of the expected size.

Samples of cDNA diluted with water (1:5) were used for both semi-quantitative and qPCR analyses. For semiquantitative RT-PCR, $1 \mu \mathrm{l}$ of cDNA was collected from each synthesized samples and from four cultivars, including salt treatments and Controls and bulked together into one tube. Regular PCR was performed in a $15 \mu \mathrm{l}$ reaction containing $1 \mu \mathrm{l}$ of bulked cDNA, $1 \times$ supplied Reaction buffer, $1.8 \mathrm{mM} \mathrm{MgCl}_{2}, 0.2 \mathrm{mM}$ each of dNTP, $0.25 \mu \mathrm{M}$ of each primer and 1.0 unit of Go-Taq DNA polymerase (Promega, USA). Amplification was carried out in a Thermal MyCycler (BioRad, USA) with the following program: $94{ }^{\circ} \mathrm{C}$ for $2 \mathrm{~min}$; 30 cycles of $94{ }^{\circ} \mathrm{C}$ for $10 \mathrm{~s}, 55^{\circ} \mathrm{C}$ for $10 \mathrm{~s}$, and $72^{\circ} \mathrm{C}$ for $15 \mathrm{~s}$; and with a final extension at $72{ }^{\circ} \mathrm{C}$ for $1 \mathrm{~min}$. The amplicon size of PCR products varied between 136 and $165 \mathrm{bp}$ (Additional file 1, Table S1). PCR products were separated by electrophoresis in 1.5\% agarose gels stained with GelRed (Biotium, USA) with a $100 \mathrm{bp}$ DNA Ladder (Bioline, USA), and visualized under UV light using a GelDoc system (BioRad, USA).

For qPCR expression analysis, a Real-Time qPCR system, Model CFX96 (BioRad, USA) was used following the qPCR protocol described earlier [31]. The total volume $(10 \mu \mathrm{l})$ of qPCR in each well included $5 \mu \mathrm{l}$ of $2 \times$ KAPA SYBR FAST (KAPA Biosystems, USA), $4 \mu \mathrm{l}$ of diluted cDNA, and $1 \mu \mathrm{l}$ of two gene-specific primers $(3 \mu \mathrm{M}$ of each primer; Additional file 1, Table S1) as per the manufacturer's recommendation. Expression data for the target genes were calculated with normalisation of gene expression relative to the average expression of the two reference genes: ADP-ribosylation factor 1-like protein $(H v A D P)$, AJ508228, and Glycolytic glyceraldehyde-3phosphate dehydrogenase $(H v G A P D H), \mathrm{X} 60343$ [32]. At least three biological and two technical replicates were used in each qPCR experiment.

\section{DNA extraction and SNP Amplifluor genotyping}

Five uniform plants were selected from each cultivar and breeding line from the segregating population grown in field trials, and the youngest fully-developed leaves were collected into $10-\mathrm{ml}$ plastic tubes separately (non- 
bulked), representing five biological replicates for each cultivar and breeding line. DNA was extracted from leaf samples with phenol-chloroform as described in our earlier papers [33]. One $\mu \mathrm{l}$ of total genomic DNA was checked on a $0.8 \%$ agarose gel to assess quality, and concentration was measured by Nano-Drop (ThermoFisher, USA).

Amplifluor-like SNP analysis was carried out using a CFX96 Real-Time PCR Detection System (BioRad, USA) using DNA samples as described previously $[21,34]$ with the following adjustment for barley genotyping. Each reaction with a total volume of $10 \mu \mathrm{l}$ contained: $3 \mu \mathrm{l}$ of template DNA adjusted to $20 \mathrm{ng} / \mu \mathrm{l}, 1 \mu \mathrm{l}$ of the two fluorescently-labelled Universal probes mix $(0.125 \mu \mathrm{M}$ each), $1 \mu \mathrm{l}$ of allele-specific primer mix $(0.075 \mu \mathrm{M}$ of each of two forward primers and $0.39 \mu \mathrm{M}$ of the common reverse primer), and $2 \mu \mathrm{l}$ of $5 \times$ Go-Taq Master-mix (Promega, USA) with the following final concentration of components: $1.75 \mathrm{mM} \mathrm{MgCl}, 0.2 \mathrm{mM}$ of dNTP and 0.05 units of Go-Taq polymerase (Promega, USA). The annotated SNP sites were used to design allele-specific primers. Sequences of the Universal probes and primers, and sizes of amplicons generated are presented in Additional file 1 (Fig. S2).

PCR was conducted using a program adjusted from those published earlier [21, 35]: initial denaturation, $95^{\circ} \mathrm{C}, 2 \mathrm{~min} ; 20$ 'doubled' cycles of $95^{\circ} \mathrm{C}$ for $10 \mathrm{~s}, 60^{\circ} \mathrm{C}$ for $10 \mathrm{~s}, 72^{\circ} \mathrm{C}$ for $20 \mathrm{~s}, 95^{\circ} \mathrm{C}$ for $10 \mathrm{~s}, 55^{\circ} \mathrm{C}$ for $20 \mathrm{~s}$ and $72{ }^{\circ} \mathrm{C}$ for $50 \mathrm{~s}$; with recording of allele-specific fluorescence after each cycle. Genotyping by SNP calling was determined automatically by the instrument software, but each SNP result was also checked manually using amplification curves and final allele discrimination. The experiments were repeated twice with two technical replicates, confirming the confidence of SNP calls.

\section{Statistical analysis}

IBM SPSS Statistical software was used to calculate and analyse means and standard error using ANOVA, and to estimate the probabilities for significance using Student's $t$-test. A correlation analysis $\mathrm{R}^{2}$ was performed using Tests of Between-Subjects Effects (IBM SPSS, Statistics Desktop 25.0.0.0).

\section{Supplementary information}

Supplementary information accompanies this paper at https://doi.org/10. 1186/s12870-020-02332-4.

Additional file 1: Figure S1. Fragments of sequences in 3'-UTR region of HVSAP12 gene in two barley parents, Granal and Baisheshek. Figure S2. Position of SNP, primer design, sequences of the Universal probes and SNP-specific primers, and size of amplicons. Table S1. Primers used for semi-quantitative RT-PCR and GPCR analysis of 17 HVSAP genes and two Reference genes including amplicon sizes and oligonucleotide sequences.

\section{Abbreviations}

KATU: Kazakh AgroTechnical University; SAP: stress associated protein: SNP: single nucleotide polymorphisms; TNF: tumor necrosis factor

\section{Acknowledgements}

We want to thank the staff and students of Flinders University of South Australia, SA (Australia) and S. Seifullin Kazakh AgroTechnical University, NurSultan (Kazakhstan) for their support in this research and help with critical comments to the manuscript.

\section{About this supplement}

This article has been published as part of BMC Plant Biology Volume 20 Supplement 1, 2020: Selected articles from the 5th International Scientific Conference "Plant genetics, genomics, bioinformatics, and biotechnology" (PlantGen2019). The full contents of the supplement are available online at https://bmcplantbiol.biomedcentral.com/articles/supplements/volume-20supplement-1.

\section{Authors' contributions}

$A B$ and $M A$ conducted experimental parts for plant growth and gene expression; AK and SJ advised, arranged and supervised experiments in Kazakhstan; MM and AZ carried out PCR, sequencing and genotyping; GS, RP and SS made crosses and conducted the field trial analysis; PL advised and supervised hybrid analysis, and edited the final version of the manuscript; CS assisted and analysed data for the hydroponics experiment, and edited the initial version of the manuscript; CLDJ advised and supervised bioinformatics data analysis, and edited the improved version of the manuscript; KLS advised and supervised gene expression analysis in Australia; YS assisted with and supervised all experiments, and wrote the first version of the manuscript. All authors read and approved of the final manuscript.

\section{Funding}

This study was supported by the Ministry of Education and Science. Kazakhstan, Research program BR05236500 (SJ). Publication costs are funded by the program. The funder had no role in study design, data collection analysis and interpretation, decision to publish, or preparation of the manuscript.

\section{Availability of data and materials}

All generated and analysed data during this study are included in this published article and its additional files.

Ethics approval and consent to participate

Not applicable.

\section{Consent for publication}

Not applicable.

\section{Competing interests}

The authors declare that they have no competing interests.

\section{Author details}

${ }^{1}$ Faculty of Agronomy, S. Seifullin Kazakh AgroTechnical University, Nur-Sultan, Kazakhstan. ${ }^{2}$ College of Science and Engineering, Biological Sciences, Flinders University, Adelaide, SA, Australia. ${ }^{3}$ A.F. Khristenko Karaganda Agricultural Experimental Station, Karaganda, Kazakhstan. ${ }^{4}$ Wheat Initiative, Julius-Kühn-Institute, Berlin, Germany.

Received: 29 January 2020 Accepted: 6 March 2020 Published: 14 October 2020

\section{References}

1. Dixit VM, Green S, Sarma V, Holzman LB, Wolf FW, O'Rourke K, Ward PA, Prochownik EV, Marks RM. Tumor necrosis factor-a induction of novel gene products in human endothelial cells including a macrophage-specific chemotaxin. J Biol Chem. 1990;265(5):2973-8.

2. Giri J, Dansana PK, Kothari KS, Sharma G, Vij S, Tyagi AK. SAPs as novel regulators of abiotic stress response in plants. Bioessays. 2013;35(7):639-48. https://doi.org/10.1002/bies.201200181. 
3. Jin $Y$, Wang $M$, Fu J, Xuan N, Zhu Y, Lian Y, Jia Z, Zheng J, Wang G. Phylogenetic and expression analysis of ZnF-AN1 genes in plants. Genomics. 2007;90(2):265-75. https://doi.org/10.1016/j.ygeno.2007.03.019.

4. Mukhopadhyay A, Vij S, Tyagi AK. Overexpression of a zinc-finger protein gene from rice confers tolerance to cold, dehydration, and salt stress in transgenic tobacco. Proc Natl Acad Sci U S A. 2004;101(16):6309-14. https:// doi.org/10.1073/pnas.0401572101

5. Vij S, Tyagi AK. Genome-wide analysis of the stress associated protein (SAP) gene family containing A20/AN1 zinc-finger(s) in rice and their phylogenetic relationship with Arabidopsis. Mol Gen Genomics. 2006;276(6): 565-75. https://doi.org/10.1007/s00438-006-0165-1.

6. Solanke AU, Sharma MK, Tyagi AK, Sharma AK. Characterization and phylogenetic analysis of environmental stress-responsive SAP gene family encoding A20/AN1 zinc finger proteins in tomato. Mol Gen Genomics. 2009; 282(2):153-64. https://doi.org/10.1007/s00438-009-0455-5.

7. Martin RC, Glover-Cutter K, Baldwin JC, Dombrowski JE. Identification and characterization of a salt stress-inducible zinc finger protein from Festuca arundinacea. BMC Res Notes. 2012;5:66. https://doi.org/10.1186/1756-0500-5-66.

8. Liu J, Yang $X$, Yang $X, X u$ M, Liu J, Xue M, Ma P. Isolation and characterization of LCSAP, a Leymus chinensis gene which enhances the salinity tolerance of Saccharomyces cerevisiae. Mol Biol Rep. 2017;44(1):5-9. https://doi.org/10.1007/s11033-016-4091-y.

9. Chang J, Zhang J, Mao X, Li A, Jia J, Jing R. Polymorphism of TaSAP1-A1 and its association with agronomic traits in wheat. Planta. 2013;237(6):1495-508. https://doi.org/10.1007/s00425-013-1860-X.

10. Gao W, Long L, Tian X, Jin J, Liu H, Zhang H, Xu F, Song C. Genome-wide identification and expression analysis of stress-associated proteins (SAPs) containing A20/AN1 zinc finger in cotton. Mol Gen Genomics. 2016;291(6): 2199-213. https://doi.org/10.1007/s00438-016-1252-6.

11. Lloret A, Conejero A, Leida C, Petri C, Gil-Muñoz F, Burgos L, Badenes ML, Ríos $\mathrm{G}$. Dual regulation of water retention and cell growth by a stressassociated protein (SAP) gene in Prunus. Sci Rep. 2017;71:332. https://doi.org/ 10.1038/s41598-017-00471-7.

12. Dong Q, Duan D, Zhao S, Xu B, Luo J, Wang Q, Huang D, Liu C, Li C, Gong $X$, Mao K, Ma F. Genome-wide analysis and cloning of the apple stressassociated protein gene family reveals MdSAP15, which confers tolerance to drought and osmotic stresses in transgenic Arabidopsis. Int J Mol Sci. 2018; 19(9):2478. https://doi.org/10.3390/ijms19092478.

13. He X, Xie S, Xie P, Yao M, Liu W, Qin L, Liu Z, Zheng M, Liu H, Guan M, Hua W. Genome-wide identification of stress-associated proteins (SAP) with A20/AN1 zinc finger domains associated with abiotic stresses responses in Brassica napus. Environ Exper Bot. 2019;165:108-19. https://doi.org/10.1016/j.envexpbot.2019.05.007.

14. Zhou Y, Zeng L, Chen R, Wang Y, Song J. Genome-wide identification and characterization of stress-associated protein (SAP) gene family encoding A20/AN1 zinc-finger proteins in Medicago truncatula. Arch Biol Sci. 2018; 70(1):87-98. https://doi.org/10.2298/ABS170529028Z.

15. Stegmann M, Monaghan J, Smakowska-Luzan E, Rovenich H, Lehner A, Holton N, Belkhadir Y, Zipfel C. The receptor kinase FER is a RALF-regulated scaffold controlling plant immune signaling. Science. 2017;355(6322):287-9. https://doi.org/10.1126/science.aal2541.

16. Liu S, Wang J, Jiang S, Wang H, Gao Y, Zhang H, Li D, Song F. Tomato SISAP3, a member of the stress-associated protein family, is a positive regulator of immunity against Pseudomonas syringae pv. tomato DC3000. Mol Plant Pathol. 2019;20(6):815-30. https://doi.org/10.1111/mpp.12793.

17. Liu S, Yuan X, Wang Y, Wang H, Wang J, Shen Z, Gao Y, Cai J, Li D, Song F. Tomato stress-associated protein 4 contributes positively to immunity against necrotrophic fungus Botrytis cinerea. Mol Plant-Microbe Interact. 2019;32(5):566-82. https://doi.org/10.1094/MPMI-04-18-0097-R.

18. Dixit AR, Dhankher OP. A novel stress-associated protein 'AtSAP10' from Arabidopsis thaliana confers tolerance to nickel, manganese, zinc, and high temperature stress. PLoS One. 2011;6(6):e20921. https://doi.org/10.1371/ journal.pone.0020921.

19. Sharma G, Giri J, Tyagi AK. Rice OsiSAP7 negatively regulates ABA stress signalling and imparts sensitivity to water-deficit stress in Arabidopsis. Plant Sci. 2015;237:80-92. https://doi.org/10.1016/j.plantsci.2015.05.011.

20. Ben Saad R, Safi H, Ben Hsouna A, Brini F, Ben RW. Functional domain analysis of LmSAP protein reveals the crucial role of the zinc-finger A20 domain in abiotic stress tolerance. Protoplasma. 2019. https://doi.org/10. 1007/s00709-019-01390-2.

21. Jatayev S, Kurishbaev A, Zotova L, Khasanova G, Serikbay D, Zhubatkanov A, Botayeva M, Zhumalin A, Turbekova A, Soole K, Langridge P, Shavrukov Y.
Advantages of Amplifluor-like SNP markers over KASP in plant genotyping BMC Plant Biol. 2017;17:254. https://doi.org/10.1186/s12870-017-1197-x.

22. Schramm C, Kurishbaev A, Jatayev S, Anderson P, Shavrukov Y. Development of single nucleotide polymorphism (SNP) markers for cereal breeding and crop research: current methods and future prospects. In: Ordon F, Friedt W, editors. Advances in Crop Breeding Techniques. Cambridge: Burleigh Dodds Science Publishing; 2019. https://doi.org/10. 19103/AS.2019.0051.16

23. IBSC, International Barley Sequencing Consortium. Assessed 5 Oct 2019. https://imagefpc.public.iastate.edu/IBSC\%20Webpage/IBSC\%20Templatehome.html.

24. Hasunuma K, editor. Barley: physical properties, genetic factors and environmental impacts on growth. NY: Nova Science Publisher; 2014.

25. Shavrukov Y. Salt stress or salt shock: which genes are we studying? J Exp Bot. 2013;64:119-27. https://doi.org/10.1093/jxb/ers316.

26. Biel W, Jacyno E. Chemical composition and nutritive value of spring hulled barley varieties. Bulg J Agric Sci. 2013;19(4):721-7.

27. Shavrukov Y, Bovill J, Afzal I, Hayes JE, Roy SJ, Tester M, Collins NC. HVP10 encoding $\mathrm{V}$-PPase is a prime candidate for the barley HVNax3 sodium exclusion gene: evidence from fine mapping and expression analysis. Planta. 2013;237:1111-22. https://doi.org/10.1007/s00425-012-1827-3.

28. Shavrukov $Y$, Genc $Y$, Hayes J. The use of hydroponics in abiotic stress tolerance research. In: Asao T, editor. Hydroponics. A Standard Methodology for Plant Biological Researches. Rijeka: InTech Open Access Publisher; 2012. p. 39-66.

29. Shavrukov Y, Gupta NK, Miyazaki J, Baho MN, Chalmers KJ, Tester M, Langridge P, Collins NC. HvNax3 - a locus controlling shoot sodium exclusion derived from wild barley (Hordeum vulgare ssp. spontaneum). Funct Integr Genomics. 2010;10:277-91. https://doi.org/10.1007/s10142-009-0153-8.

30. Huson DH, Bryant D. Application of phylogenetic networks in evolutionary studies. Mol Biol Evol. 2006;23:254-67. https://doi.org/10.1093/molbev/msj030.

31. Shavrukov $Y$, Zhumalin A, Serikbay D, Botayeva M, Otemisova A, Absattarova A, Sereda G, Sereda S, Shvidchenko V, Turbekova A, Jatayev S, Lopato S, Soole K, Langridge P. Expression level of the DREB2-type gene, identified with Amplifluor SNP markers, correlates with performance, and tolerance to dehydration in bread wheat cultivars from northern Kazakhstan. Front Plant Sci. 2016;7:1736. https://doi.org/10.3389/fpls.2016.01736.

32. Ferdous J, Li Y, Reid N, Langridge P, Shi BJ, Tricker PJ. Identification of reference genes for quantitative expression analysis of microRNAs and mRNAs in barley under various stress conditions. PLoS One. 2015;10(3): e0118503. https://doi.org/10.1371/journal.pone.0118503.

33. Zotova L, Kurishbayev A, Jatayev S, Khassanova G, Zhubatkanov A, Serikbay D, Sereda S, Sereda T, Shvidchenko V, Lopato S, Jenkins C, Soole K, Langridge $P$, Shavrukov $Y$. Genes encoding transcription factors TaDREB5 and TaNFYC-A7 are differentially expressed in leaves of bread wheat in response to drought, dehydration and ABA. Front Plant Sci. 2018;9:1441. https://doi.org/10.3389/fpls.2018.01441.

34. Zotova L, Kurishbayev A, Jatayev S, Goncharov NP, Shamambayeva N, Kashapov A, Nuralov A, Otemissova A, Sereda S, Shvidchenko V, Lopato S, Schramm C, Jenkins C, Soole K, Langridge P, Shavrukov Y. The general transcription repressor TaDr1 is co-expressed with TaVrn1 and TaFT1 in bread wheat under drought. Front Genet. 2019;10:63. https://doi.org/10. 3389/fgene.2019.00063.

35. Khassanova G, Kurishbayev A, Jatayev S, Zhubatkanov A, Zhumalin A, Turbekova A, Amantaev B, Lopato S, Schramm C, Jenkins C, Soole K, Langridge P, Shavrukov Y. Intracellular vesicle trafficking genes, RabC-GTP, are highly expressed under salinity and rapid dehydration but downregulated by drought in leaves of chickpea (Cicer arietinum L.). Front Genet. 2019;10:-40. https://doi.org/10.3389/fgene.2019.00040.

\section{Publisher's Note}

Springer Nature remains neutral with regard to jurisdictional claims in published maps and institutional affiliations. 